\title{
ASSESSMENT OF THE HEAVY METAL POLLUTION LEVEL OF THE RIVER SEDIMENTS IN THE EAST DONBASS (ROSTOV REGION, RUSSIA)
}

\author{
Zakrutkin V. E., Reshetnyak V. N., Reshetnyak O. S. \\ ОЦЕНКА УРОВНЯ ЗАГРЯЗНЕНИЯ ТЯЖЕЛЫМИ МЕТАЛЛАМИ ДОННЫХ \\ ОТЛОЖЕНИЙ РЕК ВОСТОЧНОГО ДОНБАССА \\ (РОСТОВСКАЯ ОБЛАСТЬ, РОССИЯ)
}

\author{
Закруткин В. Е., Решетняк В. Н., Решетняк О. С
}

\begin{abstract}
Introduction. River bottom sediments are a significant link in the biogeochemical cycles of water bodies and an accumulator of pollutants. The purpose of this study is to assess the level of heavy metal pollution of river sediments within the coal-mining areas of the East Donbass (Rostov Region, Russian Federation) to assess the potential risk for the population using surface water as a source of water supply. Methods. It is suggested to use the pelitic fraction for a more accurate assessment of the heavy metal pollution level of river sediments. It is proposed to use the average continental shale concentration as a baseline value for the pelitic fraction. Contamination factor $\left(C_{f}\right)$, degree of contamination $\left(C_{d}\right)$ and geo-accumulation index $\left(I_{g e o}\right)$ were used to assess the degree of heavy metal pollution of the bottom sediments in the East Donbass rivers. Results. Studies of the chemical composition and the level of bottom sediments pollution in the East Donbass rivers showed that the concentration values of heavy metals vary greatly. Assessing the degree of heavy metal pollution of the river sediments in the East Donbass allows us to classify them mainly as moderately contaminated (uncontaminated to moderately contaminated). At the same time, the level of river sediments pollution in the Seversky Donets basin is generally lower than that in the Tuzlov basin. Conclusion. The results will be used to improve the system for assessing water and bottom sediments quality in the region as well as evaluate the environmental risk to public health. Although the results showed a moderate level of heavy metal contamination of the East Donbass rivers sediments, the potential hazard of secondary pollution of the aquatic environment with metals deposited in sediments remains. Pollution of water and river bottom sediments is directly linked to the potential risk to public health because these rivers are used as sources of drinking water for towns and countryside.
\end{abstract}

Keywords: river bottom sediments, pelitic fraction, heavy metals, degree of contamination, geo-accumulation index, rivers of the East Donbass, coal-mining areas.

\begin{abstract}
Аннотация
Введение. Донные отложения являются важным звеном биогеохимических циклов в водных объектах и депонирующей средой загрязняющих веществ. Цель настоящего исследования - оценка уровня загрязненности тяжелыми металлами донных отложений рек в пределах углепромышленных территорий Восточного Донбасса (Ростовская область, РФ) для оценки потенциального риска для населения, использующего поверхностные воды в качестве источника водоснабжения. Методы. Для более корректной оценки уровня загрязненности тяжелыми металлами донных отложений рек предложено использовать пелитовую фракцию. В качестве условного фона для пелитовой фракции предлагается использовать кларки глин и глинистых сланцев. Для оценки степени загрязненности тяжелыми металлами донных отложений рек Восточного Донбасса использованы следующие общепринятые показатели: фактор загрязнения $\left(C_{f}\right)$, степень загрязнения $\left(C_{d}\right)$ и индекс геоаккумуляции донных отложений $\left(I_{g e o}\right)$. Результаты. Проведенные исследования химического состава и уровня загрязнения донных отложений рек Восточного Донбасса показали, что концентрации тяжелых металлов в них варьируются в широких пределах. Оценка степени загрязненности тяжелыми металлами донных отложений рек Восточного Донбасса позволяет отнести их преимущественно к умеренно загрязненным (от низкого до умеренного). При этом уровень загрязнения донных отложений рек в бассейне Северского Донца в целом ниже, чем в бассейне Тузлова. Заключение. Полученные результаты будут использованы при совершенствовании системы оценки качества воды и донных отложений в регионе, а также для оценки экологического риска для населения. Несмотря на то что полученные результаты показали умеренный уровень загрязнения тяжелыми металлами донных отложений рек Восточного Донбасса, сохраняется потенциальная опасность вторичного загрязнения водной среды металлами, депонируемыми в донных отложениях. Загрязнение воды и донных отложений рек напрямую связано с потенциальным риском для здоровья населения, поскольку данные водотоки используются в качестве источников питьевого водоснабжения городов и поселков.
\end{abstract}

Ключевые слова: донные отложения, пелитовая фракция, тяжелые металлы, уровень загрязнения, индекс геоаккумуляции, реки Восточного Донбасса, углепромышленные территории. 


\section{Introduction}

River sediments in the biogeochemical systems of freshwater bodies have great and specific significance. They mainly determine the direction of various processes and affect the biogeochemical cycles of substances inside the water body. As is known, river bottom sediments play a dual role: they are both an accumulator of pollutants and a source of secondary water pollution under certain conditions $[11,15]$. Lately, the concentration of various pollutants in river sediments has been an order of magnitude higher than their concentration in the water due to an increasing anthropogenic impact on river ecosystems. This is especially true for areas with developed industries [14].

The river sediments contamination problem is, on the one hand, local (point sources of technogenic pollution are identified by the level of bottom sediments contamination), but on the other hand, it is observed in river basins globally.

For example, elevated concentrations of metals are observed in the stream sediments of headwater catchments of the Han River basin, China, within the area with mining/smelting enterprises. Scientists studied the 18 metals/metalloids (Ag, As, Ba, Cd, $\mathrm{Co}, \mathrm{Cr}, \mathrm{Cu}, \mathrm{Mn}, \mathrm{Mo}, \mathrm{Ni}, \mathrm{Pb}, \mathrm{Sb}, \mathrm{Sn}, \mathrm{Tl}, \mathrm{U}, \mathrm{V}, \mathrm{Zn}$, and $\mathrm{Hg}$ ) content in the river sediments and discovered elevated concentrations of $\mathrm{Hg}$ and $\mathrm{Sb}$ caused by mining and smelting activities [16].

Researchers from Portugal [2] examined the influence of the Panasqueira Mine (Portugal) on stream sediments and river water. This research permits a better understanding of the dynamics of some elements distribution (mainly $\mathrm{As}$, but also $\mathrm{Cu}$, $\mathrm{Pb}, \mathrm{Zn}$, and $\mathrm{Cd}$ ) in the surrounding environment. The mining and beneficiation processes at the Panasqueira Mine are called the main reason for the elevated contents of $\mathrm{As}, \mathrm{Cu}, \mathrm{Cd}$ and $\mathrm{Zn}$ for most stream sediments and river water within the surrounding area. A study of the mineral composition of river sediments confirms that the pollution is associated with the influx of the mine waste.

Elevated concentrations of arsenic and heavy metals $(\mathrm{Cd}, \mathrm{Cr}, \mathrm{Cu}, \mathrm{Fe}, \mathrm{Mn}, \mathrm{Pb}$, and $\mathrm{Zn})$ are also found in stream sediments within an agricultural catchment of Lebanon, Northeastern USA [7]. The authors suggest that increased concentrations and distribution of these elements in river sediments are associated with a combination of weathering processes on the bedrock geology, and anthropogenic activities.

Researchers from Iran [8] studied the content of $\mathrm{Cu}, \mathrm{Zn}, \mathrm{As}, \mathrm{Cd}, \mathrm{Pb}, \mathrm{Fe}, \mathrm{Ni}, \mathrm{Cr}, \mathrm{Co}$, and $\mathrm{Sr}$ in the river sediments of the Haraz River (Iran) at several sampling sites. The level of sediment contamination was estimated using enrichment factor $(E F)$, geoaccumulation index $\left(I_{g e o}\right)$, and pollution index $\left(I_{\text {poll }}\right)$. The results of metal content assessment showed higher concentrations of $\mathrm{Cd}, \mathrm{As}, \mathrm{Sr}$ and $\mathrm{Pb}$ in the river sediments when compared with their background content in the crust and shales.

The main source of metal contamination of the Siran River sediments (Pakistan) is not a specific source of pollution, but the anthropogenic activity in the research area in general [10].

Similar problems are also observed in the catchment areas within the mining territories of Russia such as the Kuznetsk and Kizelovsky coal basins, Taldy-Dyurgun coal deposit (Altai Republic) and within the area of abandoned mines of the Russian Far East, etc.

The East Donbass, which is located in the west part of the Rostov Region (in the south of Russia) is a natural geochemically anomalous zone. Natural complexes within the East Donbass have been affected by negative anthropogenic impact for several decades primarily due to the coal mining industry facilities. The most significant negative environmental consequence is the release of highly mineralized mine water to soil and into river waters $[4,15]$.

Small rivers are the most affected. A huge amount of heavy metals enters the rivers with mine waters, including compounds of iron, manganese, strontium, copper, and also sulfate ions. The chemical composition of both water and river sediments changes, and the mineralogical composition of the bottom sediments is also transformed. Therefore, it becomes important to evaluate their qualitative and quantitative composition as well as the possibility of pollutants migration from river sediments into the water.

\section{Objects and methods of research}

Studies of river sediments of the East Donbass were carried out in the period from 2014 to 2019. The rivers of the Seversky Donets basin (Kalitva, Kundryuchya, Bystraya, Likhaya, Bolshaya Gnilusha, Bolshaya and Malaya Kamenka rivers) 
and Tuzlov basin (Bolshoy and Maly Nesvetay, Ayuta, Grushevka, Kadamovka and Atyukhta rivers) were selected as the objects of the study because these basins are subject to different levels of anthropogenic impact.

Special attention was paid to the small rivers of the region as they have the low self-cleaning ability and are a sensitive indicator of the general ecological state of the catchment areas.

A sampling of river sediments was carried out in points located in the headwaters or areas outside the zone of significant anthropogenic influence and in the lower reaches of the rivers to assess the total impact of various technogenic pollution sources on the catchment areas, as well as in the areas with coalmining industry facilities (existing and abandoned mines, places of mine water discharge, etc.). The layout of the sampling points is shown in Figure 1.

Several samples (usually from 3 to 5) were taken in each sampling point due to the heterogeneity of river sediments. The sampling was carried out from the upper layer of $10-20 \mathrm{~cm}$. It is assumed that the pollutants in this layer of sediments will most actively interact with the surface water. The samples were taken along the transverse profile of the river on small watercourses and near the water edge in

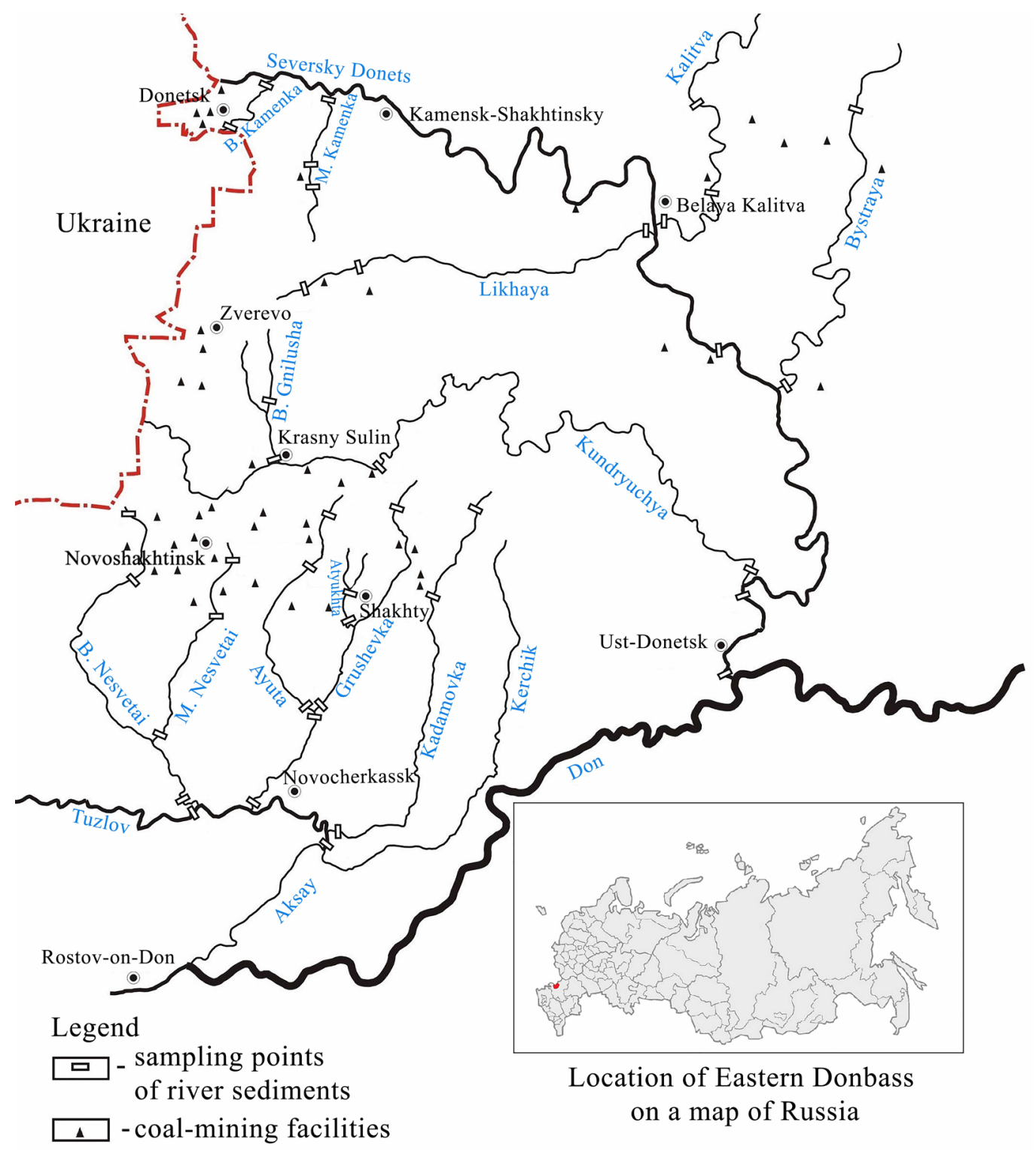

Figure 1. Layout of river sediments' sampling points of the East Donbass rivers 
places of visible sediment accumulation on medium and large rivers.

Sampling for geochemical studies was carried out with a bottom grab sampler. The mass of the taken river sediments from each sampling point varies from 1000 to $1500 \mathrm{~g}$. After a morphological description, the samples of river sediments were reduced to a dry condition. Then, we carried out a grain size analysis of the samples and determined the mineral composition of the extracted fractions. The samples prepared in this way were sent to the laboratory for heavy metal content analyses by atomic absorption spectrometry using a Kvant-2AT atomic absorption spectrometer.

A number of calculation methods were used to assess the degree of contamination of the river sediments in the East Donbass: contamination factors and degree of contamination proposed in [5] and geo-accumulation index $I_{\text {geo }}$ proposed in [6]. Despite the fact that these criteria were developed many years ago, they have been widely used in recent years $[1,3,8-10]$.

\section{Degree of contamination $\left(C_{d d}\right)$}

This method proposed by Håkanson is based on the calculation for each pollutant of a contamination factor $\left(C_{f}\right)$. Contamination factor $\left(C_{f}\right)$ is the ratio of the element concentration in the studied sediments to its pre-industrial or baseline content [5], which is calculated by the following formula (1):

$$
C_{f}=\frac{C_{X}}{C_{b}}
$$

where

$C_{X}$ is the element content in the contaminated sediments,

$C_{b}$ is the average clarke or baseline content of the element.

Concentration factors of studied elements are used in calculating the degree of contamination $\left(C_{d}\right)$, whose formula (2) is given below:

$$
C_{d}=\sum_{i=1}^{8} C_{f}^{i} .
$$

There is a descriptive scale that correlates the obtained values with the qualitative characteristics to assess the level of contamination of the studied sediments. In case of using the data on 8 elements, the values of the degree of contamination can be categorized according to Håkanson (1980) into four degrees as follows: $C_{d}<8$ (low degree of contamination), $8<C_{d}<16$ (moderate degree of contamination), $16<C_{d}<32$ (considerable degree of contamination) and $C_{d}>32$ (very high degree of contamination).

\section{Geo-accumulation index $\left(I_{\text {ged }}\right)$}

The geo-accumulation index $\left(I_{g e o}\right)$ proposed by Müller (1969) was used to estimate the degree of sediments contamination by elements in terms of 7 enrichment classes based on the increasing numerical values of the index. This index is calculated according to formula (3):

$$
I_{\text {geo }}=\log _{2} \frac{C_{X}}{1.5 \cdot C_{b}}
$$

where

$C_{X}$ is the element content in the contaminated sediments,

$C_{b}$ is the average clarke or baseline content of the element.

A factor of 1.5 is introduced to minimize the effect of possible variations in the background values of the element content in bottom sediments. The scale for assessing the level of sediments pollution by the geo-accumulation index is presented in Table 1 . It is noteworthy that in this descriptive scale, there are also intermediate gradations characterizing the transition from one state to another in addition to the main ones (low - moderate - high - extremely high) of the level of pollution. The $I_{\text {geo }}$ values of the studied elements are assigned the corresponding value of the $I_{\text {geo }}$ class. The characteristics of the river sediments quality for the sampling point or the river are assigned according to the minimum and maximum $I_{\text {geo }}$ class values, for example, " $0-3$ " class is matched to "from uncontaminated to moderately to strongly contaminated" sediment quality.

Taking into account the fact that the river sediments of the Seversky Donets and Tuzlov River basins are characterized by a large variety of grain size distribution with a predominance of poorly sorted sediments, it is preferable to use not gross samples, but the pelitic fraction (up to $0.01 \mathrm{~mm}$ ) extracted from them in order to compare the degree of sediments contamination in different rivers. This is justified for a number of reasons. Firstly, the pelitic component dominates the vast majority of sediments samples. Secondly, the pelitic fraction is the main carrier of the most elements. Thirdly, being in the most prolonged contact with the aquatic environment, the pelitic fraction stores information 
Table 1

Descriptive scale for the geo-accumulation index $\left(I_{\text {geo }}\right)[1]$

\begin{tabular}{|c|c|l|}
\hline$I_{\text {geo }}$ class & $I_{\text {geo }}$ value & $\begin{array}{c}\text { Level of contamination / Designation } \\
\text { of sediment quality }\end{array}$ \\
\hline 0 & $<0$ & Uncontaminated \\
\hline 1 & $0-1$ & $\begin{array}{l}\text { Uncontaminated to moderately } \\
\text { contaminated }\end{array}$ \\
\hline 2 & $1-2$ & Moderately contaminated \\
\hline 3 & $2-3$ & Moderately to strongly contaminated \\
\hline 4 & $3-4$ & Strongly contaminated \\
\hline 5 & $4-5$ & Strongly to extremely contaminated \\
\hline 6 & $>5$ & Extremely contaminated \\
\hline
\end{tabular}

about its state for a long time. And, finally, when studying the pelitic fraction of river sediments in the East Donbass region, we comply with the sample uniformity, which is the basic requirement in comparative geochemistry.

It is proposed to use average continental shale as a baseline metal concentration for the pelitic fraction. In particular, the average content of elements in shale according to [12] was chosen for this work.

\section{Results and discussion}

As previous studies have shown, the bottom sediments of most East Donbass rivers in terms of grain size distribution are represented by poorly differentiated psammite-silt material. At the same time, the sand component predominates (12-92\%, on average 54\%) in the river sediments of the Seversky Donets basin and the clay fraction prevails in the river sediments of the Tuzlov basin (34-76\%, on average $65 \%$ ). It is confirmed by the data presented in Figure 2, which shows the position of the figurative points of sediments in a certain field of the Sheppard diagram. It is seen that the river sediments of the Tuzlov basin are more concentrated in the transition zone from sand to clay (silt), while the sediments of the Seversky Donets rivers are characterized by a more heterogeneous composition [4].

The river sediments of the Seversky Donets basin have the following chemical composition (according to analyses of 76 samples): the iron content varies from 5500 to $26,600 \mathrm{mg} / \mathrm{kg}$, manganese - from 170 to $4000 \mathrm{mg} / \mathrm{kg}$, nickel - from 13 to $300 \mathrm{mg} / \mathrm{kg}$, zinc - from 42 to $300 \mathrm{mg} / \mathrm{kg}$, chromium - from 36 to $150 \mathrm{mg} / \mathrm{kg}$, copper — from 15 to $100 \mathrm{mg} / \mathrm{kg}$, lead — from 10 to $57 \mathrm{mg} / \mathrm{kg}$, and cobalt — from 5 to $50 \mathrm{mg} / \mathrm{kg}$. The main components of the chemical composition of the bottom sediments in the Tuzlov basin (according to analyses of 74 samples) are the same metals: iron content varies from 14,800 to $39,200 \mathrm{mg} / \mathrm{kg}$, manganese — from 414 to $3400 \mathrm{mg} / \mathrm{kg}$, chromium - from 91 to $840 \mathrm{mg} / \mathrm{kg}$, zinc — from 43 to $300 \mathrm{mg} / \mathrm{kg}$, copper — from 17 to $200 \mathrm{mg} / \mathrm{kg}$, nickel — from 22 to $116 \mathrm{mg} / \mathrm{kg}$, lead — from 10 to $107 \mathrm{mg} / \mathrm{kg}$ and cobalt — from 7 to $28 \mathrm{mg} / \mathrm{kg}$.

Iron prevails among other elements in the chemical composition of the sediments in terms of absolute contents. The content of manganese is an order of magnitude lower than the content of iron. Other metals contents are even lower than the content of manganese. In general, we can claim that the concentration of metals in the sediments of the Tuzlov basin rivers is higher than in the river sediments of the Seversky Donets basin. First of all, this fact is due to a higher anthropogenic load in the Tuzlov basin and a greater negative impact of manmade mine water, which will be discussed in more detail below.

Degree of contamination $\left(C_{d}\right)$ and contamination factor $(C)$

Contamination factors $\left(C_{f}\right)$ for each element were calculated for the East Donbass rivers, the sum of $C_{f}$ gives the degree of contamination $\left(C_{d}\right)$ of sediments. The calculation results of these indicators are shown in Table 2.

Table 2 shows that for the Seversky Donets basin, contamination factors exceeding 1 are noted for the following metals: lead (for all rivers); manganese (for 4 rivers); zinc (for 5 rivers); cobalt (for 4 rivers), etc. It should be noted that no excess of baseline concentrations (average shale concentrations) was detected for iron. On average, the largest values in the basin are noticed for $\mathrm{Pb}$ (1.7), $\mathrm{Mn}$ (1.3), $\mathrm{Zn}$ (1.2), and $\mathrm{Co}(1.1)$; the $C_{f}$ values of the remaining elements do not exceed 1.0.

It can be seen (Table 2) that there is a certain difference between the distribution of elements in sediments for rivers of the Seversky Donets and Tuzlov basins. Chromium prevails (the average $C_{f}$ value is 2.7) for sediments of the Tuzlov basin and its contamination factor values are exceeded for all seven rivers. The values of contamination factors also exceed 1 for the following metals: lead (1.5) for 6 rivers, copper (1.4) for 3 rivers, zinc (1.3) for 5 rivers, manganese (1.2) for 2 rivers (Table 2). In general, the values of contamination factors as well 
as the degree of contamination of sediments for the rivers of the Tuzlov basin are higher than the values for the Seversky Donets basin.

\section{Geo-accumulation index $\left(I_{\text {ged }}\right)$}

Geo-accumulation indices $\left(I_{\text {geo }}\right)$ calculations (Table 3) show that among the rivers of the Seversky Donets basin, Bolshaya Gnilusha is the most polluted river. The values of the $I_{g e o}$ index characterize the level of pollution with elements as "uncontaminated to moderately contaminated" for 5 elements and "moderately contaminated" for manganese. For other rivers, deviations from the "uncontaminated" state are observed for 1-2 elements. These deviations are the most frequently observed for lead. The level of river sediments pollution within the Seversky Donets basin with heavy metals can be generally assessed as "uncontaminated".

The values of the geo-accumulation index are generally higher for the river sediments of the Tuzlov basin than for the sediments of the Seversky Donets basin, especially for chromium (Table 3 ). The majority of the river sediments samples within the Tuzlov river basin are characterized as "uncontaminated to moderately contaminated" or "moderately contaminated" sediments. The most polluted sediments are observed at sampling points of the Atyukhta and Grushevka rivers. There are deviations from the "uncontaminated" sediment quality by three elements in these samples.

Thus, when comparing the descriptions of the contamination levels of river sediments obtained using Russian and international indices, it can be seen that, in general, they are quite similar. The sediments of the Kalitva, Bystraya, Seversky Donets rivers in the Seversky Donets basin and the Kadamovka river in the Tuzlov basin are the least polluted. The most polluted sediments belong to the Bolshaya Gnilusha and Grushevka rivers. In general, the level of river sediments pollution within both basins is characterized as "moderate" (according to the degree of contamination indicator), "uncontaminated" or transitional "uncontaminated to moderately contaminated" (according to the geoaccumulation index). However, at the same time, metal contamination of river sediments is lower for the Seversky Donets basin than for the Tuzlov basin.

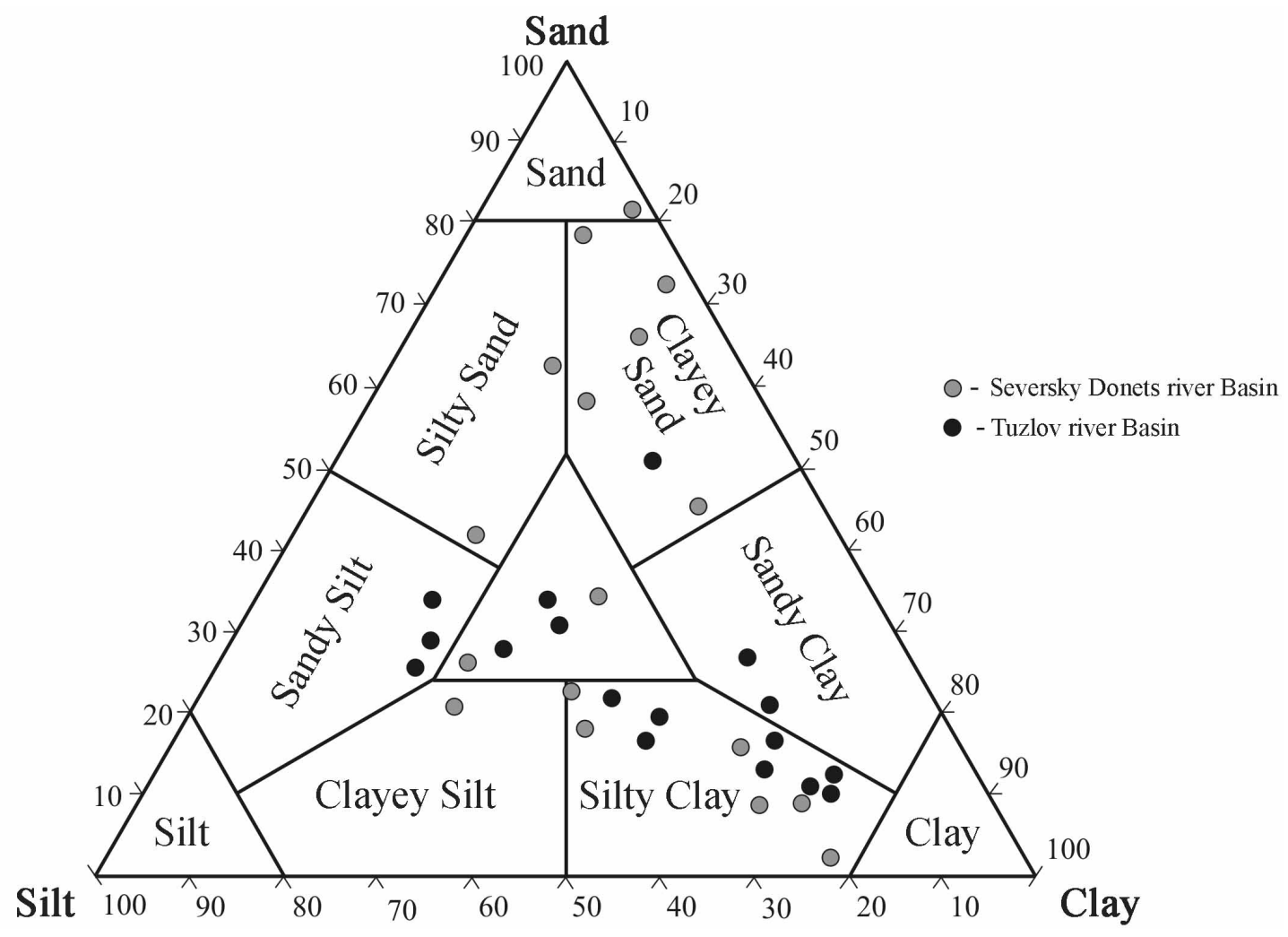

Figure 2. Grain size distribution of the East Donbass rivers sediments [4] 
Table 2

Contamination factors $\left(C_{f}\right)$ and degree of contamination $\left(C_{d}\right)$ of the river sediments in the East Donbass

\begin{tabular}{|c|c|c|c|c|c|c|c|c|c|}
\hline \multirow{2}{*}{ River } & \multicolumn{8}{|c|}{ Contamination factors $\left(C_{f}\right)$} & \multirow{2}{*}{$C_{d}$} \\
\hline & $\mathrm{Fe}$ & $\mathrm{Co}$ & $\mathrm{Mn}$ & $\mathrm{Cu}$ & $\mathrm{Ni}$ & $\mathrm{Pb}$ & $\mathrm{Zn}$ & $\mathrm{Cr}$ & \\
\hline \multicolumn{10}{|c|}{ Seversky Donets river basin } \\
\hline Bolshaya Kamenka & 0.5 & 1.2 & 1.3 & 1.0 & 1.0 & 2.4 & 1.3 & 1.0 & 9.8 \\
\hline Malaya Kamenka & 0.4 & 1.0 & 0.8 & 0.9 & 0.8 & 2.2 & 1.3 & 0.9 & 8.3 \\
\hline Likhaya & 0.4 & 1.9 & 2.1 & 1.4 & 1.4 & 1.5 & 1.4 & 1.0 & 11.1 \\
\hline Kalitva & 0.3 & 0.5 & 0.4 & 0.5 & 0.5 & 1.2 & 0.6 & 0.6 & 4.8 \\
\hline Bystraya & 0.4 & 0.7 & 0.7 & 0.7 & 0.5 & 1.5 & 0.9 & 0.8 & 6.2 \\
\hline Kundryuchya & 0.4 & 1.2 & 1.3 & 0.8 & 1.0 & 1.9 & 1.3 & 1.0 & 9.0 \\
\hline Bolshaya Gnilusha & 0.4 & 1.9 & 3.2 & 1.5 & 2.6 & 1.6 & 2.2 & 1.3 & 14.6 \\
\hline Seversky Donets & 0.1 & 0.3 & 0.3 & 0.4 & 0.3 & 1.0 & 0.9 & 0.5 & 3.8 \\
\hline Average (for the basin) & 0.4 & 1.1 & 1.3 & 0.9 & 1.0 & 1.7 & 1.2 & 0.9 & 8.5 \\
\hline \multicolumn{10}{|c|}{ Tuzlov river basin } \\
\hline Bolshoy Nesvetay & 0.6 & 0.7 & 2.0 & 0.7 & 0.6 & 1.4 & 0.9 & 1.5 & 8.5 \\
\hline Maly Nesvetay & 0.6 & 1.2 & 2.0 & 0.7 & 1.2 & 1.2 & 1.2 & 3.2 & 11.2 \\
\hline Ayuta & 0.7 & 0.7 & 0.7 & 1.0 & 0.8 & 2.7 & 1.3 & 4.0 & 11.7 \\
\hline Atyukhta & 0.7 & 0.7 & 0.5 & 1.3 & 0.9 & 2.0 & 1.6 & 3.0 & 10.7 \\
\hline Grushevka & 0.8 & 0.9 & 2.1 & 1.6 & 1.0 & 1.3 & 1.5 & 4.7 & 13.8 \\
\hline Kadamovka & 0.6 & 0.6 & 0.7 & 0.6 & 0.6 & 1.1 & 0.7 & 1.3 & 6.2 \\
\hline Tuzlov & - & 1.1 & 0.8 & 3.9 & 0.8 & 0.9 & 2.1 & 1.1 & 10.7 \\
\hline Average (for the basin) & 0.7 & 0.8 & 1.2 & 1.4 & 0.8 & 1.5 & 1.3 & 2.7 & 10.4 \\
\hline
\end{tabular}

Note: the color indicates the level of pollution of river sediments: green corresponds to low degree; yellow — to moderate degree.

Table 3

Geo-accumulation index $\left(I_{\text {geo }}\right)$ of metals in the river sediments of the East Donbass

\begin{tabular}{|c|c|c|c|c|c|c|c|c|c|}
\hline \multirow{2}{*}{ River } & \multicolumn{8}{|c|}{ Geo-accumulation index $\left(I_{g e o}\right)$} & \multirow{2}{*}{$I_{g e o}$ class } \\
\hline & $\mathrm{Fe}$ & $\mathrm{Co}$ & $\mathrm{Mn}$ & $\mathrm{Cu}$ & $\mathrm{Ni}$ & $\mathrm{Pb}$ & $\mathrm{Zn}$ & $\mathrm{Cr}$ & \\
\hline \multicolumn{10}{|c|}{ Seversky Donets river basin } \\
\hline Bolshaya Kamenka & -1.53 & -0.38 & -0.18 & -0.53 & -0.56 & 0.69 & -0.16 & -0.58 & $0-1$ \\
\hline Malaya Kamenka & -1.79 & -0.65 & -0.87 & -0.80 & -0.84 & 0.53 & -0.16 & -0.70 & $0-1$ \\
\hline Likhaya & -1.78 & 0.31 & 0.51 & -0.11 & -0.10 & -0.01 & -0.06 & -0.62 & $0-1$ \\
\hline Kalitva & -2.54 & -1.46 & -1.76 & -1.48 & -1.58 & -0.29 & -1.21 & -1.32 & 0 \\
\hline Bystraya & -1.98 & -1.01 & -1.15 & -1.02 & -1.51 & -0.04 & -0.78 & -0.84 & 0 \\
\hline Kundryuchya & -1.74 & -0.37 & -0.18 & -0.83 & -0.60 & 0.37 & -0.22 & -0.63 & $0-1$ \\
\hline Bolshaya Gnilusha & -1.83 & 0.36 & 1.08 & 0.02 & 0.80 & 0.05 & 0.52 & -0.22 & $0-2$ \\
\hline Seversky Donets & -3.35 & -2.11 & -2.57 & -1.95 & -2.44 & -0.53 & -0.76 & -1.70 & 0 \\
\hline \multicolumn{10}{|c|}{ Tuzlov river basin } \\
\hline Bolshoy Nesvetay & -1.36 & -1.08 & 0.40 & -1.11 & -1.21 & -0.07 & -0.77 & 0.02 & $0-1$ \\
\hline Maly Nesvetay & -1.41 & -0.37 & 0.41 & -1.05 & -0.38 & -0.33 & -0.33 & 1.09 & $0-2$ \\
\hline Ayuta & -1.10 & -1.17 & -1.17 & -0.66 & -0.96 & 0.85 & -0.26 & 1.41 & $0-2$ \\
\hline Atyukhta & -1.03 & -1.12 & -1.45 & -0.22 & -0.76 & 0.40 & 0.10 & 1.00 & $0-2$ \\
\hline Grushevka & -0.96 & -0.75 & 0.46 & 0.10 & -0.60 & -0.16 & -0.01 & 1.63 & $0-2$ \\
\hline Kadamovka & -1.37 & -1.34 & -1.14 & -1.27 & -1.29 & -0.50 & -1.08 & -0.18 & 0 \\
\hline Tuzlov & - & -0.51 & -0.87 & 1.37 & -0.89 & -0.78 & 0.49 & -0.43 & $0-2$ \\
\hline
\end{tabular}

Note: the color indicates the degree of contamination of river sediments according to the $I$ value: green corresponds to uncontaminated sediments; yellow - to uncontaminated to moderately contaminated sediments. 
This heterogeneity in the level of contamination of the river sediments of the two basins is rather due to the level of technogenic impact from coal mining enterprises than to the environmental conditions. The influence of mine water is more explicit within the Tuzlov basin.

There is a greater number of active and abandoned coal mines in the Tuzlov basin, and the total outflow of mine water is more than 8 times greater than in the Seversky Donets basin. Thus, according to [13], the Tuzlov tributaries are subject to an annual discharge of up to 363,375 tons of various pollutants, including macrocomponents such as sulfates, sodium and potassium ions, chlorides and hydrocarbons, and microcomponents such as iron, manganese, copper, strontium, aluminum, etc. This is several times higher than the total amount of components discharged with mine water in the Seversky Donets basin (42,128 tons per year).

The negative impact of mine water causes a decline in the river water quality of the studied basins [14]. The water quality is matched to the $4^{\text {th }}$ (dirty or very dirty water) and $5^{\text {th }}$ (extremely dirty water) quality classes used in Russia on a five-grade quality scale. This contradicts our results in assessing the level of river sediments pollution. However, such difference can be explained by the fact that when assessing water quality, the maximum available concentrations (MAC) of substances established for all river basins in Russia are used. These MACs are applied equally to areas with different climatic conditions and specifics of anthropogenic impact on the environment. Meanwhile, when assessing the level of river sediments pollution, regional background concentrations of elements or clarkes are applied. Using different evaluation criteria and baseline concentrations leads to such discrepancies in the results. This once again shows the need to review and control the MAC-concept used in Russia. It is necessary to introduce the basin principle using the background geochemical characteristics of the individual watersheds when assessing water quality and bottom sediments, as it has been done in many European countries for many years.

We also need to note that despite the fact that the obtained results demonstrate a moderate level of contamination of the East Donbass river sediments, the potential hazard of secondary pollution of the aquatic environment by metals deposited in the river sediments remains. Pollution of water and river sediments is directly related to the potential risk to public health because these streams are used as sources of drinking water for towns and in the countryside. Hydroecological risk increases not only with a decline of river water quality but also with an increase in the population (with an increase of the demographic load on the river basins) [15].

That is why our further research will be developed in the direction of assessing the risk to public health and the risk to irrigation and agriculture because the studied region is one of the leading agricultural regions of the Russian Federation.

\section{Conclusions}

The results of the studies show that the chemical composition of the river sediments in the technologically disturbed geosystems of the East Donbass (within the basins of the Seversky Donets and Tuzlov rivers) is characterized by a similar set of elements (heavy metals). Their concentrations vary greatly. The highest content in the river sediments of both basins is observed for iron and manganese, the lowest - for lead and cobalt. In general, the concentration of metals in the river sediments for the Tuzlov basin is higher than that for the Seversky Donets basin.

An assessment of the contamination level of river bottom sediments with heavy metals was carried out using various indicators $\left(C_{d}\right.$ and $\left.I_{\text {geo }}\right)$. The low pollution level was revealed for the majority of rivers, at the same time, on average for the Seversky Donets basin, the level of bottom sediments contamination is lower than that for the Tuzlov river basin, which is associated with a more intense anthropogenic load.

The results of using various approaches to assessing the river sediments contamination level are quite comparable. However, the low contamination level of river bottom sediments is not consistent with the high level of river water pollution within the technologically disturbed geosystems of the East Donbass. This can be explained by the use of different evaluation criteria for two interconnected environments: baseline concentrations (clarkes) for river bottom sediments and MAC for the river waters.

These new data can be used for the development and improvement of the regional system for the assessment of the water quality and bottom sediments contamination level. The results will be applicable for assessing the environmental risk for a population 
that actively uses river water as a drinking water source and for technical purposes.

\section{References}

1. Abrahim, G. M. S. and Parker, R. J. (2008). Assessment of heavy metal enrichment factors and the degree of contamination in marine sediments from Tamaki Estuary, Auckland, New Zealand. Environmental Monitoring and Assessment, Vol. 136, Issues 1-3, pp. 227-238. DOI: 10.1007/s10661-007-9678-2.

2. Ávila, P. F., Da Silva, E. F., Salgueiro, A. R. and Farinha, J. A. (2008). Geochemistry and mineralogy of mill tailings impoundments from the Panasqueira Mine (Portugal): implications for the surrounding environment. Mine Water and the Environment, Vol. 27, Issue 4, article No. 210. DOI: 10.1007/ s10230-008-0046-4.

3. Cao, X., Shao, Y., Deng, W., Wang, H. and Wang, S. (2014). Spatial distribution and potential ecologic risk assessment of heavy metals in the sediments of the Nansi Lake in China. Environmental Monitoring and Assessment, Vol. 186, Issue 12, pp. 8845-8856. DOI: 10.1007/s10661-014-4048-3.

4. Gibkov, E. V., Zakrutkin, V. E., Reshetnyak, V. N. and Reshetnyak, O. S. (2020). Ecological and geochemical features of the river sediments of East Donbass. Bulletin of Higher Educational Institutions. North Caucasus Region. Natural Science, No. 1, pp. 36-46. DOI: 10.18522/1026-2237-2020-1-36-46.

5. Hakanson, L. (1980). An ecological risk index for aquatic pollution control, a sedimentological approach. Water Research, Vol. 14, Issue 8, pp. 975-1001. DOI: 10.1016/00431354(80)90143-8.

6. Müller, G. (1969). Index of geoaccumulation in the sediments of the Rhine River. Geojournal, 2, pp. 108-118.

7. Oyewumi, O., Feldman, J. and Gourley, J. R. (2017). Evaluating stream sediment chemistry within an agricultural catchment of Lebanon, Northeastern USA. Environmental Monitoring and Assessment, Vol. 189, Issue 4, article No. 141. DOI: $10.1007 / \mathrm{s} 10661-017-5856-\mathrm{z}$.

8. Nasrabadi, T., Nabi Bidhendi, G., Karbassi, A. and Mehrdadi, N. (2010). Evaluating the efficiency of sediment metal pollution indices in interpreting the pollution of Haraz River sediments, southern Caspian Sea basin. Environmental Monitoring and Assessment, Vol. 171, Issue 1-4, pp. 395-410. DOI: 10.1007/s10661-009-1286-x.

9. Pazi, I. (2011). Assessment of heavy metal contamination in Candarli Gulf sediment, Eastern Aegean Sea. Environmental Monitoring and Assessment, Vol. 174, Issue 1-4, pp. 199-208. DOI:10.1007/s10661-010-1450-3.

10. Raza, A., Farooqi, A., Javed, A. and Ali, W. (2016). Distribution, enrichment, and source identification of selected heavy metals in surface sediments of the Siran River, Mansehra, Pakistan. Environmental Monitoring and Assessment, Vol. 188, Issue 10, article No. 572. DOI: 10.1007/s10661-016-5586-7.

11. Reshetnyak, O. S. and Zakrutkin, V. E. (2016). Bottom sediments as a source of secondary water pollution by metals (according to the laboratory experiment). Bulletin of Higher Educational Institutions. North Caucasus Region. Natural Science, No. 4, pp. 102-109. DOI: 10.18522/0321-3005-20164-102-109.

12. Turekian, K. K., and Wedepohl, D. H. (1961). Distribution of the elements in some major units of the earth's crust. GSA Bulletin, Vol. 72, No. 2, pp. 175-192. DOI: 10.1130/0016-7606(1961)72[175:DOTEIS]2.0.CO;2.

13. Zakrutkin, V. E., Ivanik, V. M. and Gibkov, E. V. (2010). Ecology-geographical analyses of coal industry risks restructure in Eastern Donbass. Izvestiya Rossiiskoi Akademii Nauk. Seriya Geograficheskaya, No. 5, pp. 94-102.

14. Zakrutkin, V. E., Sklyarenko, G. Yu., Bakaeva, E. N., Reshetnyak, O. S., Gibkov, E. V. and Fomenko, N. E. (2016). Surface water and groundwater within technologically disturbed geosystems of the East Donbass: formation of chemical composition and quality assessment. Rostov-on-Don: Southern Federal University.

15. Zakrutkin, V. E., Gibkov, E. V., Reshetnyak, O. S. and Reshetnyak, V. N. (2020). River sediments as river waters' primary pollution indicator and secondary pollution source in East Donbass coal-mining areas. Izvestiya Rossiiskoi Akademii Nauk. Seriya Geograficheskaya, Vol. 84, No. 2, pp. 259-271. DOI: $10.31857 / \mathrm{S} 2587556620020168$.

16. Wei, L., Cai, M., Du, Y., Tang, J., Wu, Q., Xiao, T., Luo, D., Huang, X., Liu, Y., Fei, Y. and Chen, Y. (2019). Spatial attenuation of mining/smelting-derived metal pollution in sediments from tributaries of the upper Han River, China. Mine Water and the Environment, Vol. 38, Issue 2, pp. 410-420. DOI: 10.1007/s10230-018-00583-0.

Authors

Zakrutkin Vladimir Yevgenyevich, Dr. of Geology and Mineralogy, Professor

Southern Federal University, Rostov-on-Don, Russia

E-mail: vezak@list.ru

\section{Reshetnyak Viktor Nikolaevich}

Southern Federal University, Rostov-on-Don, Russia «All-Russian Research Geological Exploration Institute of Coal deposits», Rostov-on-Don, Russia

E-mail: vnresh3@gmail.com

Reshetnyak Olga Sergeevna, $\mathrm{PhD}$ in Geography, Associate Professor

Southern Federal University, Rostov-on-Don, Russia

Hydrochemical Institute, Rostov-on-Don, Russia

E-mail: olgare1@mail.ru,osreshetnyak@sfedu.ru

\section{Авторы}

Закруткин Владимир Евгеньевич, д-р геологоминерал. наук, профессор Россия

Южный федеральный университет, Ростов-на-Дону,

E-mail: vezak@list.ru,

\section{Решетняк Виктор Николаевич} Россия

Южный федеральный университет, Ростов-на-Дону,

$\mathrm{AO}$ «Всероссийский научно-исследовательский геологоразведочный институт угольных месторождений», Ростов-на-Дону, Россия

E-mail: vnresh3@gmail.com

Решетняк Ольга Сергеевна, канд. геогр. наук, доцент Россия

Южный федеральный университет, Ростов-на-Дону,

Гидрохимический институт, Ростов-на-Дону, Россия

E-mail: olgare1@mail.ru, osreshetnyak@sfedu.ru 